\title{
The theoretical bases and methodical recommendations of energy saving management in a business organization
}

ABSTRACT: The article is devoted to topical issues of energy saving management of a business organization. The concept and essence of saving are considered. Based on the systematization of the totality of manifestations of saving energy, the following types are distinguished: economic, ecological, ecological-economic, reputation and social. External and internal factors of saving energy in a business organization are identified, which reflect the conditions of its operation in the context of saving energy. It is determined that energy efficiency barriers, which are proposed to be divided into technical-economic, organizational-behavioral and cognitive, characterize the energy saving process in terms of restraining factors in improving the efficiency of fuel and energy resources, reflect specific obstacles within the energy saving process in a particular business organizations and are of an intra-organizational nature. It is determined that to improve energy saving processes in a business organization the use cycles of continuous development, in particular, the Deming cycle is advisable. For the purposes of energy management, the use an appropriate business model that determines the order of formation of the economic advantage of the entity through energy savings and reflects a set of solutions that characterize the process of creating value for stakeholders are advisable.

Corresponding Author: Olena Shatilova; e-mail: olena.shatilova@gmail.com

1 Department of Management, SHEE Kyiv National Economic University named after Vadym Hetman, Kyiv, Ukraine; ORCID iD: 0000-0003-3883-5567; e-mail: olena.shatilova@gmail.com

2020. The Author(s). This is an open-access article distributed under the terms of the Creative Commons Attribution-ShareAlike International License (CC BY-SA 4.0, http://creativecommons.org/licenses/by-sa/4.0/), which permits use, distribution, and reproduction in any medium, provided that the Article is properly cited. 
Based on the formalization of the business model of energy efficiency of the business organization, the use of an saving energy program aimed at removing barriers to energy efficiency and the impact on internal energy saving factors, as they are the levers that a business organization can influence to improve energy efficiency, is proposed.

KEYWORDS: energy saving, management, business organization, energy saving management process, energy saving business model

\section{Introduction}

The stability of functioning is the viability condition of any business organization and the basis of its development in a competitive market. At the same time, the high dependence of the economy of most countries on fuel and energy resources, the geopolitical component of the process of providing them and the instability of market prices significantly affect the competitiveness of business organizations and largely determine the specifics of their operation. These issues cause the updating of energy efficiency of a business organization and require a relevant to modern realities approaches to energy saving management. Issues of energy saving and energy efficiency have been the subject of attention of many scientists. The existing theoretical and practical developments in this field of study are importance, but most of the scientific works are devoted to the rationalization of fuel and energy resources at the macroeconomic (Dołęga 2019; Krog and Sperling 2019) and industry levels (Bhowmik et al. 2017). Instead, theoretical and methodological aspects of energy saving management in a business organization remain fragmented and require further scientific study. In particular, this concerns the development of new models of energy saving management, the theoretical foundations of the formation of competitive advantages based on it, as well as ensuring the effective management of energy savings in the business organization. The relevance of this range of problematic issues led to the choice of the topic of this study.

\section{The theoretical bases of the business organization energy saving management}

The study showed that the formation of modern approaches to energy management of a business organization took place within the evolutionary process of forming an appropriate system of scientific knowledge. It ranged from theoretical views on the economics of rational consumption of natural resources (Kudlaj and Seliverstova 2013; Janiszewska 2019; Lior 2008) to recogni- 
zing energy efficiency as an important prerequisite for the competitiveness of individual business organizations (Gökgöz and Güvercin 2018), and ensuring the stability of the state's economy (Deny 'syuk et al. eds. 2016; Ossowska and Janiszewska 2020).

Approaches to energy saving management have changed in accordance with the stages of development of the world economy in the context of the consumption of fuel and energy resources. Attention to energy saving issues at the micro level became relevant in the early 1970s due to the global energy crisis. Scientific views on the specifics of saving energy have evolved from its perception in the context of measures that provided mainly short-term savings by reducing the cost of fuel and energy resources, to the recognition of saving energy as a necessary element of a business organization's strategy. In the 21st century, the ability of a business organization to exist generally refers to the capacity for the biosphere and human civilization to coexist (UNGA 2005; Cirella et al. 2020). This is defined as the process of people maintaining change in a homeostasis balanced environment, in which the exploitation of resources, the direction of investments, the orientation of technological development and institutional change are all in harmony and enhance both the current and future potential to meet human needs and aspirations.

Saving energy in a business organization in modern business conditions, in our opinion, is a factor in obtaining both an economic effect (benefit) and other effects, in particular, environmental and economic, social, environmental and reputational. The main task of energy saving management is to increase the energy efficiency of the business organization, which is crucial for achieving economic effects. Energy efficiency characterizes the degree of consumption of fuel and energy resources per unit of final effect and determines the level of their costs, and can be identified by a set of relevant indicators, the most generalizing of which is energy consumption.

The process of saving energy and business organization should be aimed at overcoming the phenomenon of the energy efficiency gap, the emergence of which is due to the presence of its four levels: the actual, project-achievable, economically feasible and theoretically possible (Dasheng Lee and Chin-Chi Cheng 2016). In this case, the magnitude of the energy efficiency gap is determined by the action of specific energy saving factors and barriers to energy efficiency (Sorrell et al. 2011). External energy saving factors include: the global environmental, economic and social trends in the use of fuel and energy resources, the state regulation of energy efficiency and energy saving, market conditions of final products. Internal energy saving factors include: organizational characteristics of the business organizations' functioning. In contrast to energy saving factors, barriers to energy efficiency reflect specific barriers that exist in a particular business organization within the energy saving process and are formed under the influence of these external and internal conditions.

Saving energy relates to the process of strategic management of a business organization and the level of its competitiveness. The main areas of formation of competitive advantages of energy-intensive organizations are as follows: creating value for stakeholders, reducing costs and reducing dependence on fuel and energy resources, as well as the conditions of their supply. Saving energy provides the formation of all three of these additional competitive advantages. The reduction of costs is due to the reduction of consumption of fuel and energy resources, which 
affects the reduction of production costs due to its energy component. The value for stakeholders is created by the impact of saving energy on the needs of stakeholders regarding the energy consumption of the entity. The reduction of dependence on fuel and energy resources and the conditions of their supply is achieved due to the reduction of the business organization's need for energy resources, which in turn reduces uncertainty about the operating conditions. The above allows the strategic nature of saving energy and the need to use appropriate approaches to its management to be justified.

\section{The process of business organization energy saving management}

In our opinion, in order to improve the process of energy saving management in a business organization, the use of the Plan-Do-Check-Act methodology (PDCA 2020), a component of which is the creation and development of an energy saving management system, is advised. This approach ensures the continuity of the process of energy saving management, at each new cycle of which the management of this area is improved. The main stages and measures to improve the process of energy saving in a business organization are in Figure 1.

The energy saving management system should be considered as one of the functional subsystems of a business organization, which is a set of interdependent and interacting elements necessary to ensure the efficient flow of energy savings.

The subjects of the energy saving management system are the top management of the business organization, the person responsible for saving energy, the heads of departments, and the energy saving quality group. They influence the managed subsystem through the implementation of the main functions of energy saving management, such as: motivation and incentives for staff in the field of saving energy, organization and regulation of energy saving processes, development of an saving energy program, accounting and reporting on the consumption of fuel and energy resources, analysis of the effectiveness of saving energy program measures, control over the consumption of fuel and energy resources, and the implementation of the saving energy program.

The object of energy saving management is the process of energy saving. It consists of elements that simultaneously reflect its content and organizational mechanism of implementation: informing stakeholders about the results of saving energy; staff training, involvement in the process of continuous improvement of energy savings; formation of an appropriate organizational structure; investing in saving energy; compliance with energy consumption regulations; monitoring, analysis and evaluation of energy consumption.

Based on the analysis of the state of energy saving management, it can be argued that the energy saving management of most Ukrainian business organizations is characterized by frag- 


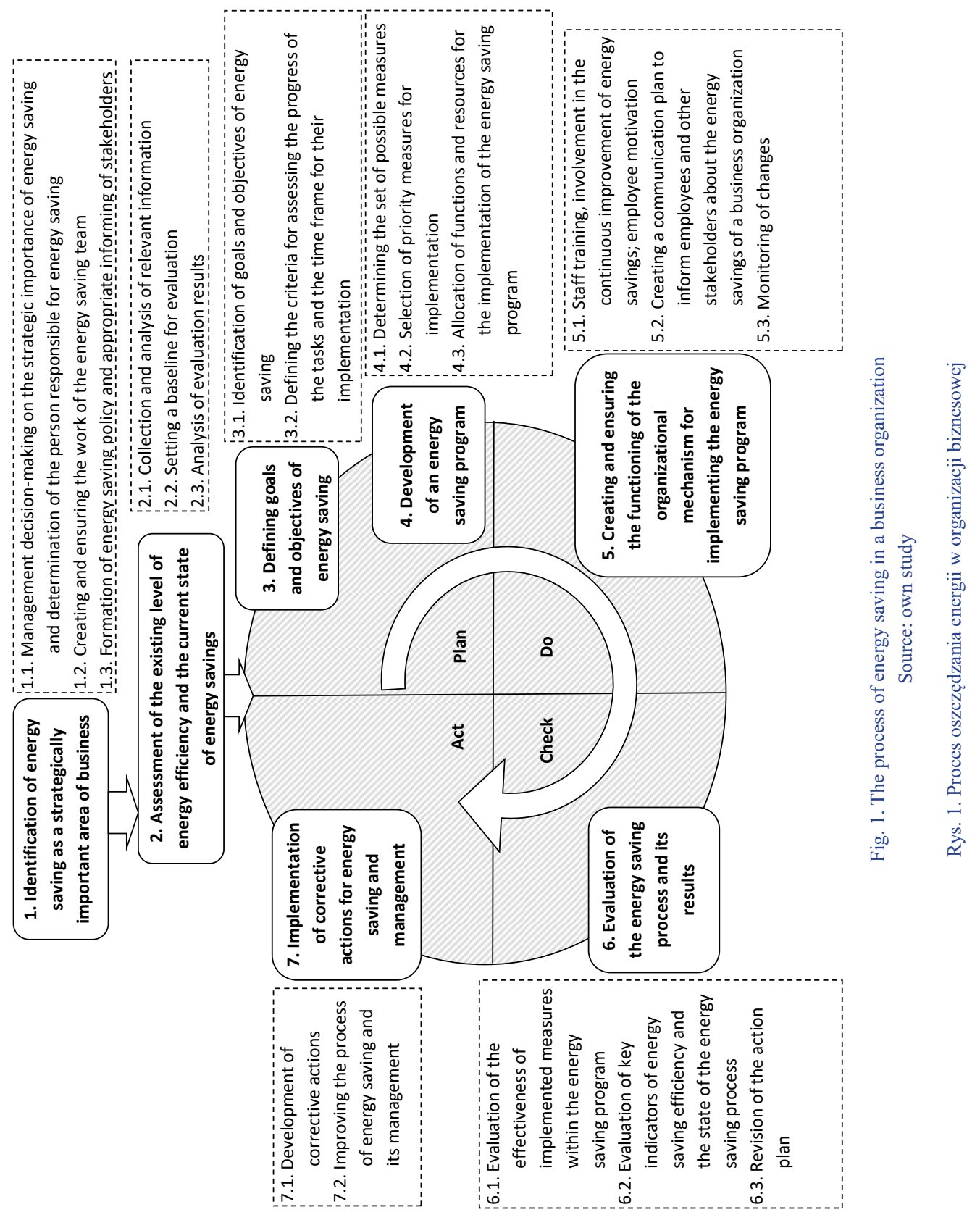


mentation. In recent years, the level of interest of owners of Ukrainian business organizations in improving the energy efficiency of their enterprises, the introduction of the practice of energy audits and energy saving policies has increased significantly. However, the situation is characterized by the existence of barriers to investing in energy efficiency, as well as the need to improve existing business models of companies. It should be noted that producers belonging to foreign groups of companies have a more comprehensive approach to saving energy, in particular, due to access to world experience in implementing energy efficient projects at other enterprises (including foreign ones) and opportunities to obtain financing within the group.

\section{Business model of a business organization energy efficient operation}

Managing a business organization's energy savings also involves transforming its business model. The business model should demonstrate the features of the business organization as a system, describe the relationship of its elements, how to create value, make a profit and provide a competitive advantage and should consist of interconnected components that form the architecture of efficient energy saving in the business organization. The content and logical content of the structural components of this business model, the existing relationships between them, which characterize the logic of efficient energy saving and management in a business organization, are shown in Figure 2.

The formalizing of such a business model is the basis for developing a set of measures that make up the saving energy program, which is the main application tool for the main task of saving energy - improving the energy efficiency of the business organization. The list of measures of the saving energy program are made within each of the internal factors of saving energy, because they are the levels that a business organization can directly influence to improve the energy efficiency of its operation and, consequently, gain an additional competitive advantages.

The main internal factors of saving energy in a business organization, in our opinion, are the following: organizational management structure, professional and psychological training of employees in the field of saving energy, production structure, conditions and sources of energy, production method, structure of production consumption, characteristics of finished products, as well as operational features of the equipment. According to this approach, all measures of the saving energy program in a business organization are proposed to be considered within two groups: technical and organizational (Fig. 3). According to the depth of changes and the amount of costs required for their implementation, these measures could be basic (low-cost), in-depth and deep, and the nature of the planned changes - to structural, technological and structural-technological. 
It should be noted that even those business organizations whose activities are associated with high-energy consumption should not only implement technical measures aimed at reducing the energy intensity of production, but also pay close attention to organizational measures

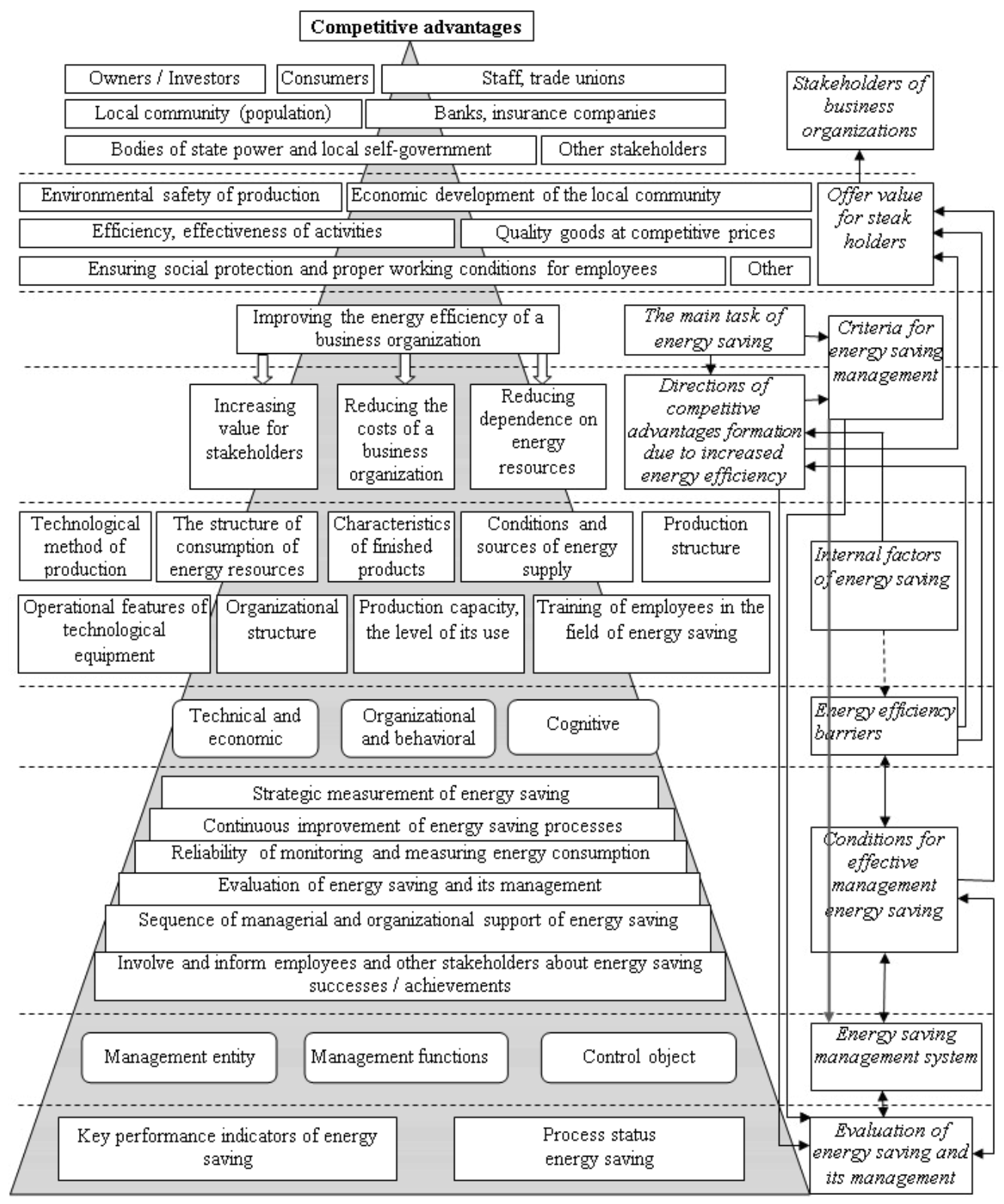

Fig. 2. Business model of energy efficient operation of a business organization Source: own study

Rys. 2. Model biznesowy efektywnego energetycznie działania organizacji biznesowej 


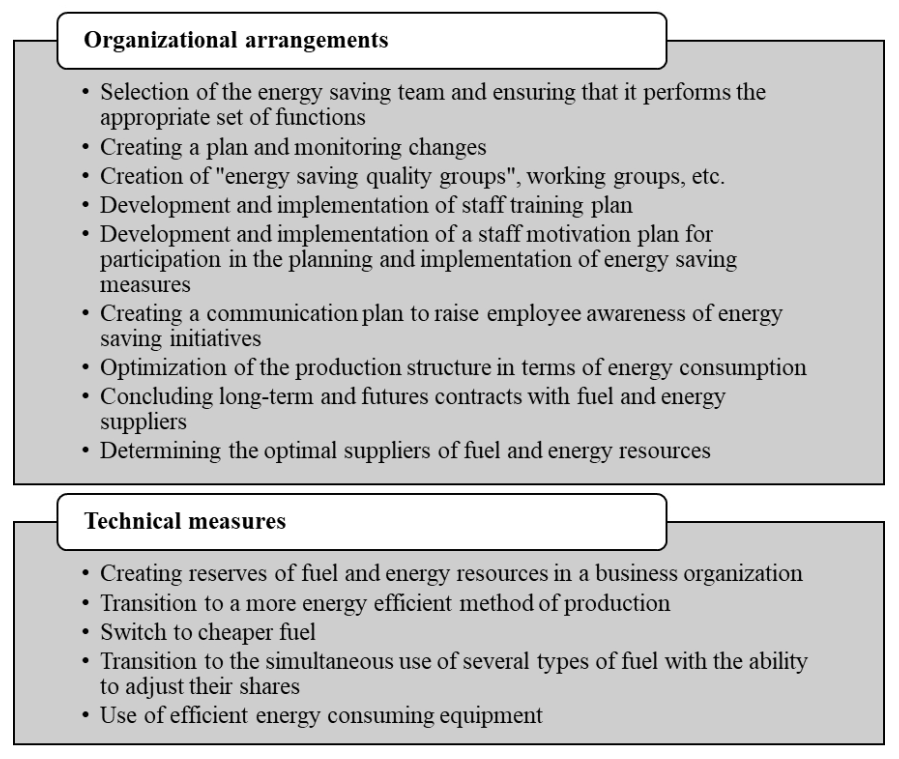

Fig. 3. Saving energy program activities in a business organization Source: own study

Rys. 3. Działania w ramach programu oszczędzania energii w organizacji biznesowej

to save energy. Organizational measures ensure the improvement of saving energy processes, their adaptation to the dynamic external environment and allow the business organization to use the potential of technical measures much more efficiently.

\section{Conclusion}

In summary, it should be noted that despite the significant theoretical and applied developments, the conceptual and categorical apparatus of saving energy processes is not stable. In particular, the terms "saving energy" and "energy efficiency" are often interchangeable. Disclosure of the above concepts through the main tasks, motives for optimizing the consumption of fuel and energy resources and the relationship of these processes with energy efficiency makes it possible to meaningfully separate these terms and define saving energy as a set of activities aimed at improving energy efficiency and saving energy volumes of energy consumption. The implementation of saving energy provides the formation of competitive advantages of energy-intensive business organizations by increasing the energy efficiency of their operation, which is primarily manifested in creating benefit for stakeholders, reducing costs and reducing dependence on fuel 
and energy resources and their supply. On this basis, the strategic nature of saving energy and the need to use appropriate approaches to the management process are substantiated. It is determined that in order to improve saving energy processes in a business organization, the use of cycles of continuous development, in particular, the Deming cycle, is advisable. For the purposes of energy management, to the use of an appropriate business model that determines the order of formation of the economic advantage of the entity through saving energy and reflects a set of solutions that characterize the process of creating value for stakeholders is advisable. Based on the formalizing of the business model of energy efficiency of the business organization, to the use of an saving energy program aimed at removing barriers to energy efficiency and the impact on internal saving energy factors, as they are the lelers that a business organization can influence to improve energy efficiency, is proposed. A promising area of further research in the field of saving saving energyin a business organization is to assess the energy efficiency of the business organization, which should be based on the use of key performance indicators that reflect changes in costs, value for stakeholders and dependence on fuel and energy resources and the conditions of their supply.

\section{References}

Bhowmik et al. 2017 - Bноwмiк, Ch., Bноwмiк, S., RaY, A. and Pandey, K.M. 2017. Optimal green energy planning for sustainable development: A review. Renewable and Sustainable Energy Reviews 71, pp. $134-136$.

Cirella et al. 2020 - Cirella, G., Goncharuk, A., lo Storto, C. and Russo, A. 2020. Exploring Social Sustainability and Economic Practices: Multi-Journal Compendium. Reprinted from: Sustainability 12, pp. 1-7, DOI: 10.3390/su12051718.

DolęGA, W. 2019. Selected aspects of national economy energy efficiency. Polityka Energetyczna - Energy Policy Journal 22(3), pp. 19-32, DOI: https://doi.org/10.33223/epj/111987.

DenY `syuk et al. eds. 2016 - DenY `syuk, S.P., Koczar, O.V. and Chernecz Ka, Yu.V. eds. 2016. Energy efficiency of Ukraine. Best project ideas [electronic edition]: Project "Professionalization and stabilization of energy management in Ukraine" (Energety 'chna efekty 'vnist 'Ukrayiny'. Krashhi proektni ideyi [elektronne vy`dannya]: Proekt «Profesionalizaciya ta stabilizaciya energety`chnogo menedzhmentu $v$ Ukrayini»). Kyiv: KPU, 79 p. (in Ukrainian).

Giuseppe et al. 2020 - Giuseppe, T.C., GoncharuK, A.G., Lo Storto, C. and Russo, A. 2020. Exploring Social Sustainability and Economic Practices: Multi-Journal Compendium. Reprinted from: Sustainability 12, pp. 1-7, DOI: 10.3390/su12051718.

GöKGÖz, F. and GÜVERCIN, M.T. 2018. Energy security and renewable energy efficiency in EU. Renewable and Sustainable Energy Reviews 96, pp. 226-239.

JANiszewsKA, D. 2019. Diversification of energy production and consumption in European Union countries. Polityka Energetyczna - Energy Policy Journal 2(22), pp. 5-19.

KroG, L. and SPERLING, K. 2019. A comprehensive framework for strategic energy planning based on Danish and international insights. Energy Strategy Reviews 24, pp. 83-93.

KudLaJ, V.S. and SELIVERSTOVA, L.S. 2013. Analysis of efficiency of use energy resources (Analiz efekty ' $v$ nosti vy 'kory 'stannya energety 'chny`x resursiv). Bulletin of KNUTD (Visny`k KNUTD) 6, pp. 49-64. (in Ukrainian). 
Lee, D. and Cheng, C.-C. 2016. Energy savings by energy management systems: A review. Renewable and Sustainable Energy Reviews 56, pp. 760-777. [Online] https://www.sciencedirect.com/science/article/ abs/pii/S1364032115013349?via\%3Dihub [Accessed: 2020-07-03].

LioR, N. 2008. Energy resources and use: The present situation and possible paths to the future. Energy 33, pp. 842-857.

NAKONEChNA, D.Yu. 2013. Prerequisites for creating an effective energy management system at the enterprise (Peredumovy`stvorennya efekty 'vnoyi sy 'stemy`upravlinnya energooshhadzhennyam na pidpry'yemstvi). Effective economics: Electronic scientific professional publication (Efekty vna ekonomika: Elektronne naukove faxove vy dannya) 1. [Online] http://www.economy.nayka.com.ua [Accessed: 2020-07-15] (in Ukrainian).

Ossowska, L.J and JANISZEwska, D.A. 2020. Toward sustainable energy consumption in the European Union. Polityka Energetyczna - Energy Policy Journal 23(1), pp. 37-48, DOI: https://doi.org/10.33223/ epj/119371.

Plan-Do-Check-Act (PDCA) 2020. Continually Improving, in a Methodical Way. Mind Tools. Emerald Works Limited. [Online] https://www.mindtools.com/pages/article/newPPM_89.htm [Accessed: 2020$-07-03]$.

Sorrell et al. 2011 - Sorrell, S., Mallett, A. and Nye, S. 2011. Barriers to industrial energy efficiency: A literature review. United Nations Industrial Development Organization. [Online] http://sro.sussex. ac.uk/id/eprint/53957/1/WP102011_Barriers_to_Industrial_Energy_Efficiency_-_A_Literature_Review.pdf [Accessed: 2020-07-03].

UNGA 2005. World Summit Outcome: Sustainable development: managing and protecting our common environment. [Online] http://daccess-dds-ny.un.org/doc/UNDOC/GEN/N05/487/60/PDF/N0548760. pdf?OpenElement [Accessed: 2020-07-03].

Olena SHATILOVA

\title{
Teoretyczne podstawy i zalecenia metodyczne zarządzania oszczędnością energii w organizacji biznesowej
}

\author{
Streszczenie
}

Artykuł poświęcony jest aktualnym zagadnieniom zarządzania oszczędnością energii $\mathrm{w}$ organizacji biznesowej. Uwzględniono koncepcję i istotę oszczędzania. Usystematyzowano występujące sposoby oszczędzania energii i wyróżniono następujące typy: ekonomiczny, ekologiczny, ekologiczno-ekonomiczny, reputacyjny i społeczny. Zidentyfikowano zewnętrzne i wewnętrzne czynniki oszczędzania energii $\mathrm{w}$ organizacji biznesowej, które odzwierciedlają uwarunkowania jej działania w tym kontekście. Zaproponowano rozróżnienie barier efektywności energetycznej, hamujących poprawę efektywności wykorzystywania paliw i zasobów energetycznych, na: techniczno-ekonomiczne, organizacyjno-behawioralne i poznawcze, co odzwierciedla konkretne przeszkody w obrębie procesu oszczędzania energii w poszczególnych organizacjach biznesowych. Stwierdzono, że w celu usprawnienia procesów oszczędzania energii 
w organizacji biznesowej wskazane jest wykorzystanie cyklów ciągłego doskonalenia, w szczególności cyklu Deminga. Na potrzeby zarządzania energią wskazane jest stosowanie odpowiedniego modelu biznesowego, który określa kolejność kształtowania korzyści ekonomicznej podmiotu poprzez oszczędzanie energii i odzwierciedla zestaw rozwiązań charakteryzujących proces tworzenia wartości dla interesariuszy. W celu poprawy efektywności energetycznej zaproponowano oparcie się na sformalizowanym modelu biznesowym efektywności energetycznej organizacji biznesowej oraz zastosowanie programu oszczędzania energii uwzględniającego usunięcie wewnętrznych przeszkód, który stanie się dźwignią dla poprawy efektywności.

SŁOWA KLUCzowe: oszczędzanie energii, zarządzanie, organizacja biznesowa, proces zarządzania oszczędzaniem energii, energooszczędny model biznesowy 
